\title{
Biochar-mediated enhanced ethanol fermentation (BMEEF) in Zymomonas mobilis under furfural and acetic acid stress
}

\author{
Wei-ting Wang ${ }^{1,2+}$, Li-chun Dai ${ }^{1 \dagger}$, Bo Wu${ }^{1}$, Bu-fan $\mathrm{Qi}^{3}$, Tian-fang Huang ${ }^{4}$, Guo-quan Hu${ }^{1}$ and Ming-xiong He ${ }^{1 *}$ (D)
}

\begin{abstract}
Background: Pretreatment of lignocellulosic biomass generates different types of inhibitors (e.g., furfural and acetic acid), which could remarkably inhibit subsequent ethanol fermentation. Here, biochar as an additive in the fermentation broth was first applied to enhance ethanol production by Z. mobilis wild-type strain ZM4 in the presence of typical inhibitors.

Results: This study showed that the biochar-mediated tolerance to furfural and acetic acid for the strain Z. mobilis ZM4 was the highest reported level, resulting in much higher ethanol productivity under stress conditions than that in non-treated conditions. Further analysis showed that adsorptive detoxification was not the controlling factor for enhanced ethanol production under stress conditions, attributed to its low removal of furfural $(<20 \%)$ and incapability of acetic acid removal. When biochar was filtered from the biochar-treated inhibitor-containing broth, it still showed enhanced ethanol production. Furthermore, Z. mobilis immobilized on biochar was also observed. Thus, biochar extracts in the fermentation broth and cell immobilization on biochar might be the controlling factors for enhanced ethanol production under stress conditions.
\end{abstract}

Conclusions: These results indicate that biochar-mediated enhanced ethanol fermentation (BMEEF) might be a promising strategy for ethanol production from lignocellulosic biomass.

Keywords: Lignocellulosic hydrolysate, Furfural, Acetic acid, Biochar, Zymomonas mobilis

\section{Background}

Cellulosic ethanol is a meaningful modern adjunct to fossil fuels and diluted acid pretreatment is one of the cost-effective methods reported and has been extensively studied [1]. However, the two most toxic inhibitors, i.e., furfural and acetic acid, were generated during this process, and these inhibitors would adversely affect the

\footnotetext{
*Correspondence: hemingxiong@caas.cn; hemxion@hotmail.com 'Wei-ting Wang and Li-chun Dai contributed equally to this work 1 Biomass Energy Technology Research Centre, Key Laboratory of Development and Application of Rural Renewable Energy (Ministry of Agriculture and Rural Affairs), Biogas Institute of Ministry of Agriculture and Rural Affairs, Section 4-13, Renmin Rd. South, Chengdu 610041, People's Republic of China

Full list of author information is available at the end of the article
}

cellular growth, metabolism, and ethanol fermentation efficiency of ethanologenic bacteria [2,3]. The minimum inhibitory tolerant levels vary from microbes but are generally below $1.5 \mathrm{~g} / \mathrm{L}$ furfural and $3.0 \mathrm{~g} / \mathrm{L}$ acetic acid, respectively $[4,5]$. Furthermore, furfural can form synergistic inhibition with acetic acid [6]. Many methods that have been studied in the past focused on removing inhibitors before fermentation (e.g., physical, physicochemical and biological) $[7,8]$ or developing inhibitor-tolerant ethanologenic strains $[9,10]$.

Zymomonas mobilis is an excellent ethanologenic bacterium possessing several appealing characteristics such as high ethanol yield and tolerance capacity, low biomass amount, and high specific rate of sugar uptake [11, 12]. But its weak tolerance to furfural and acetic acid is

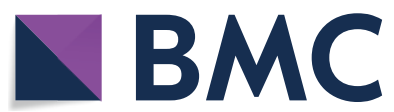

(c) The Author(s) 2020. This article is licensed under a Creative Commons Attribution 4.0 International License, which permits use, sharing, adaptation, distribution and reproduction in any medium or format, as long as you give appropriate credit to the original author(s) and the source, provide a link to the Creative Commons licence, and indicate if changes were made. The images or other third party material in this article are included in the article's Creative Commons licence, unless indicated otherwise in a credit line to the material. If material is not included in the article's Creative Commons licence and your intended use is not permitted by statutory regulation or exceeds the permitted use, you will need to obtain permission directly from the copyright holder. To view a copy of this licence, visit http://creativeco mmons.org/licenses/by/4.0/. The Creative Commons Public Domain Dedication waiver (http://creativecommons.org/publicdomain/ zero/1.0/) applies to the data made available in this article, unless otherwise stated in a credit line to the data. 
the major drawback when applied to ethanol fermentation using lignocellulose feedstock containing furfural and acetic acid generated from pretreatment [13]. Apart from removing inhibitors before fermentation, creating mutants capable of tolerating furfural and acetic acid is efficient for the economic production of cellulosic biofuels $[14,15]$. However, although several efforts have been applied to improve these inhibitors' tolerance in $Z$. mobilis, including forward and reverse genetics, so far, the reported highest concentrations of furfural and acetic acid that $Z$. mobilis could tolerate were $3.0 \mathrm{~g} / \mathrm{L}$ and $8.0 \mathrm{~g} / \mathrm{L}[10,16]$, respectively. But further efforts are still needed to meet the requirement of practical lignocellulose biorefinery with high inhibitor contents in the pretreated feedstock, and due to the complex mechanism of furfural and acetic acid stress in Z. mobilis, developing a robust strain will also be a difficult challenge [13-15].

Biochar, attributed to its special characteristics, such as high porosity, rich functional groups, abundant nutrients, is an emerging versatile material for various applications [17-23], such as soil amendment/remediation [19], crop production promotion [20], water pollution control $[17,18]$, and even anaerobic digestion [21, 22] and composting [23]. For example, in anaerobic digestion, biochar has shown its capacity in improving the fermentation of easy-acidification substrates by promoting buffering capacity [22]. However, little is known about the effects of biochar as a fermentation additive to improve ethanol fermentation by $Z$. mobilis in the presence of a high concentration of inhibitors in the hydrolysate [24, 25]. Biochar has shown its capacity in adsorptive detoxification of phenols, furfural, and 5-HMF [26-28]. However, biochar was not efficient in acetic acid adsorption. Moreover, adsorptive detoxification requires a high dose of biochar to achieve high removal of adsorbable inhibitors. A large amount of biochar for detoxification would impede its practical application. For example, the application of $4 \%$ biogas digestate-derived biochar in synthetic medium removed more than $94 \%$ of 5 -HMF and $99 \%$ of furfural after $24 \mathrm{~h}$ of contact time [28].

Here, biochar-mediated enhanced ethanol fermentation (BMEEF) was developed by applying biochar as an additive in fermentation broth to promote ethanol production by $Z$. mobilis wild-type strain ZM4 in the presence of typical inhibitors. Adsorbable furfural and non-adsorbable acetic acid were chosen as typical inhibitors in this study. Biochar for BMEEF was not applied as a detoxification agent, so its dose was $<1 / 10$ of the dose used for adsorptive detoxification [28], which was more suitable for practical application due to its much lower dose. Ethanol production under stress from furfural or acetic acid and co-stress was observed to confirm the effects of adsorptive detoxification, biochar extracts in the fermentation broth and immobilized Z. mobilis cells on biochar-enhanced ethanol production under various stress conditions. The results of this study could provide novel insights into the effects of biochar on ethanol fermentation under stress conditions.

\section{Results and discussion}

\section{Biochar enhanced ethanol production under acetic acid} stress

Through forward and reverse genetics, the reported highest concentration of acetic acid that $Z$. mobilis could tolerate was $8.0 \mathrm{~g} / \mathrm{L}$ [10]. Therefore, in this study, four different gradient concentrations (3.0, 6.0, 9.0, and $12.0 \mathrm{~g} / \mathrm{L}$ ) of acetic acid were employed. As shown in Fig. 1a, b, and Table 1, wild-type strain ZM4 was dramatically suppressed by $6.0 \mathrm{~g} / \mathrm{L}$ acetic acid and could hardly survive under $9.0 \mathrm{~g} / \mathrm{L}$ acetic acid. Actually, when a supplement of $6.0 \mathrm{~g} / \mathrm{L}$ acetic acid was added, strain ZM4 consumed $97.86 \%$ glucose within $48 \mathrm{~h}$, and when $9.0 \mathrm{~g} / \mathrm{L}$ acetic acid was added, ZM4 could hardly survive, only consumed $6.24 \pm 2 \%$ glucose within $96 \mathrm{~h}$. However, with 3.5\% biochar addition, strain ZM4 consumed $97.93 \%$ glucose and produced $25.10 \pm 0.12 \mathrm{~g} / \mathrm{L}$ ethanol within $16 \mathrm{~h}$ under $6.0 \mathrm{~g} / \mathrm{L}$ acetic acid stress condition and consumed $92.0 \%$ glucose and produced $23.58 \pm 1.03 \mathrm{~g} / \mathrm{L}$ ethanol within $48 \mathrm{~h}$ with $9.0 \mathrm{~g} / \mathrm{L}$ acetic acid addition. As reported, the highest concentration of acetic acid generated during the pretreatment step of biomass was nearly $10.0 \mathrm{~g} / \mathrm{L}$ [29]. With $3.5 \%$ biochar addition, the ZM4 strain could consume $81.51 \%$ of the initial glucose after fermentation for $84 \mathrm{~h}$ in the presence of $12.0 \mathrm{~g} / \mathrm{L}$ acetic acid. Considering that biochar was not efficient in acetic adsorption (Additional file 1: Figure S1), adsorptive detoxification might be not the controlling factor for enhanced ethanol production under acetic stress conditions. In anaerobic digestion conditions, biochar has also shown its capacity in improving the fermentation of easy-acidification substrates through its buffering capacity [22].

The BMEEF is an efficient and convenient method to promote the production of ethanol by $Z$. mobilis wildtype strain ZM4 under the high concentration of acetic acid. Compared with the reported acetic acid-tolerant $Z$. mobilis strains [4, 10, 30], biochar addition remarkably shortened the fermentation time and enhanced ethanol productivity. For example, a mutant ZMA7-2 (tolerant to $7.0 \mathrm{~g} / \mathrm{L}$ acetic acid) was obtained via three rounds of adaptive laboratory evolution (ALE) [4], which consumed 96\% glucose within $48 \mathrm{~h}$. Besides, a flocculent mutant ZM401 and mutants ZMAQ8-1 and ZMAC8-9 with high tolerance to acetic acid were obtained by nitrosoguanidine (NTG) and ARTP mutagenesis, respectively [10, 30]. For ethanol fermentation by the acetic acid-tolerable 

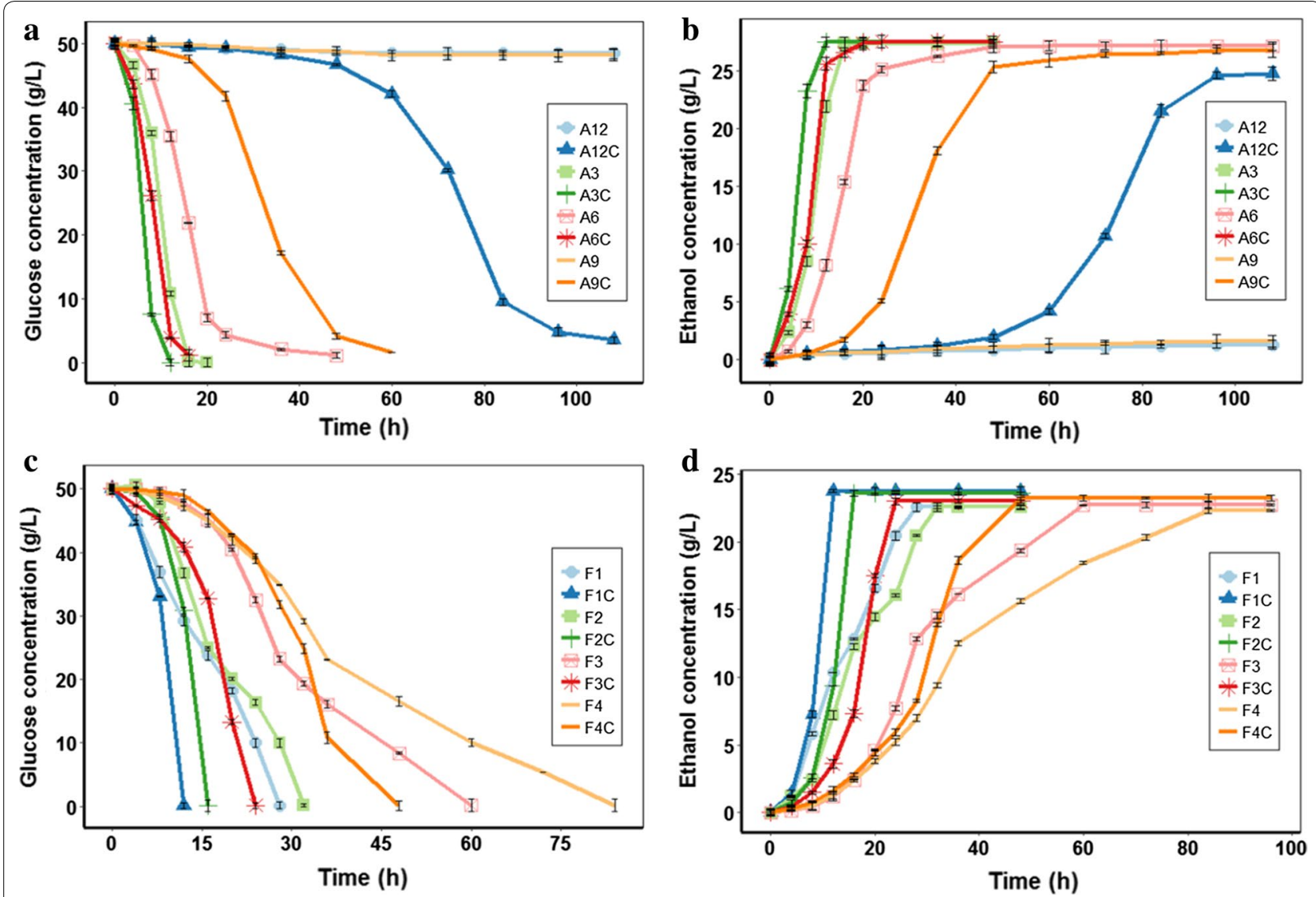

Fig. 1 Effects of biochar on ethanol fermentation by Z. mobilis ZM4 in the presence of acetic acid stress condition (a, $\mathbf{b})$, and furfural stress condition (c, d). Glucose indicates the concentration of sugar that remained in cultures. EtOH indicates the concentration of ethanol produced. "An" and "Fn" indicate $Z$. mobilis ZM4 fermented in the presence of $n \mathrm{~g} / \mathrm{L}$ acetic acid and $n \mathrm{~g} / \mathrm{L}$ furfural, respectively. "AnC" and "FnC" indicate $Z$. mobilis ZM4 co-cultured with $3.5 \%$ biochar fermented in the presence of $n \mathrm{~g} / \mathrm{L}$ acetic acid and $n \mathrm{~g} / \mathrm{L}$ furfural, respectively

mutant (ZM401), $\mathrm{pH}$ was maintained at 6.0 by $\mathrm{KOH}$ to promote ethanol production under $6.0 \mathrm{~g} / \mathrm{L}$ acetic acid. Actually, when RM was supplemented with $6.0 \mathrm{~g} / \mathrm{L}$ acetic acid, the $\mathrm{pH}$ value was 3.92 . However, the $\mathrm{pH}$ value was uncontrolled for BMEEF. Moreover, although acetic acid-tolerable mutants (ZMAQ8-1 and ZMAC8-9) could produce ethanol with a high productivity at a certain stress condition, they were still not efficient in ethanol fermentation under high concentration of acetic acid (like in the presence of $8.0 \mathrm{~g} / \mathrm{L}$ acetic acid), with the productivities of 0.32 and $0.3 \mathrm{~g} / \mathrm{L} / \mathrm{h}$, respectively (Table 1) [10]. While in the presence of $9.0 \mathrm{~g} / \mathrm{L}$ acetic acid, BMEEF by strain ZM4 could produce ethanol at a productivity of $0.39 \pm 0.02 \mathrm{~g} / \mathrm{L} / \mathrm{h}$. Thus, BMEEF was more efficient and convenient than the genetic engineering of strains.

Biochar facilitated ethanol production under furfural stress Furfural is another key inhibitor in the cellulosic hydrolysate. The highest concentration of furfural tolerated by $Z$. mobilis was $3.0 \mathrm{~g} / \mathrm{L}$ in previous studies [16, 31].
Therefore, four different gradient concentrations (1.0, 2.0, 3.0 , and $4.0 \mathrm{~g} / \mathrm{L}$ ) of furfural were employed in this study. As shown in Fig. 1c, d, and Table 1, Z. mobilis ZM4 was dramatically suppressed by over $2.0 \mathrm{~g} / \mathrm{L}$ furfural. Actually, when a supplement of $3.0 \mathrm{~g} / \mathrm{L}$ furfural was added, strain ZM4 consumed $99.64 \%$ glucose within $72 \mathrm{~h}$. When $4.0 \mathrm{~g} / \mathrm{L}$ furfural was added, strain ZM4 consumed $99.76 \%$ glucose within $84 \mathrm{~h}$ with a longer lag phase. However, with 3.5\% biochar addition, strain ZM4 consumed $99.71 \%$ glucose and produced $23.99 \pm 0.88 \mathrm{~g} / \mathrm{L}$ ethanol within $24 \mathrm{~h}$ in the presence of $3.0 \mathrm{~g} / \mathrm{L}$ furfural and consumed $99.72 \%$ glucose and produced $22.82 \pm 0.85 \mathrm{~g} / \mathrm{L}$ ethanol within $48 \mathrm{~h}$ under $4.0 \mathrm{~g} / \mathrm{L}$ furfural stress. Thus, these results indicated that the addition of biochar remarkably reduced fermentation time under furfural stress conditions.

Various furfural-tolerant mutants were developed for ethanol production under furfural conditions. For example, mutant ZMF3-3 that is tolerant to $3.0 \mathrm{~g} / \mathrm{L}$ furfural was screened through three rounds of ALE and consumed 
Table 1 Conversion of glucose to ethanol by Z. mobilis under acetic acid and/or furfural stresses

\begin{tabular}{|c|c|c|c|c|c|c|c|}
\hline \multirow[t]{2}{*}{ Strain } & \multirow{2}{*}{$\begin{array}{l}\text { Fermentation } \\
\text { time (h) }\end{array}$} & \multirow[t]{2}{*}{ Glucose consumed (g/L) } & \multicolumn{3}{|l|}{ Ethanol } & \multirow{2}{*}{$\begin{array}{l}\text { Theoretical } \\
\text { yield (\%) }\end{array}$} & \multirow[t]{2}{*}{ References } \\
\hline & & & Titer (g/L) & Yield (g/g glucose) & Productivity (g/L/h) & & \\
\hline \multicolumn{6}{|c|}{$50.0 \mathrm{~g} / \mathrm{L}$ glucose $+3.0 \mathrm{~g} / \mathrm{L}$ acetic acid } & & This study \\
\hline $\mathrm{ZM} 4+\mathrm{C}$ & 12 & $52.60 \pm 0.37$ & $26.39 \pm 0.18^{*}$ & $0.50 \pm 0.00^{* *}$ & $2.20 \pm 0.02^{* * *}$ & 97.85 & \\
\hline ZM4 & 20 & $51.79 \pm 0.58$ & $24.83 \pm 0.59$ & $0.48 \pm 0.01$ & $1.24 \pm 0.03$ & 93.93 & \\
\hline \multicolumn{8}{|c|}{$50.0 \mathrm{~g} / \mathrm{L}$ glucose $+6.0 \mathrm{~g} / \mathrm{L}$ acetic acid } \\
\hline $\mathrm{ZM} 4+\mathrm{C}$ & 16 & $51.47 \pm 0.01^{* * *}$ & $25.10 \pm 0.12^{* * *}$ & $0.49 \pm 0.00^{* * *}$ & $1.57 \pm 0.01^{* * *}$ & 95.89 & \\
\hline ZM4 & 48 & $50.61 \pm 0.05$ & $22.69 \pm 0.08$ & $0.45 \pm 0.00$ & $0.47 \pm 0.00$ & 88.06 & \\
\hline \multicolumn{8}{|c|}{$50.0 \mathrm{~g} / \mathrm{L}$ glucose $+9.0 \mathrm{~g} / \mathrm{L}$ acetic acid } \\
\hline $\mathrm{ZM} 4+\mathrm{C}$ & 60 & $51.26 \pm 0.00$ & $23.58 \pm 1.03^{* * *}$ & $0.46 \pm 0.02^{* * *}$ & $0.39 \pm 0.02$ & 90.02 & \\
\hline ZM4 & - & $51.35 \pm 0.18$ & $0.18 \pm 0.01$ & $0.00 \pm 0.00$ & - & - & \\
\hline \multicolumn{8}{|c|}{$50.0 \mathrm{~g} / \mathrm{L}$ glucose $+12.0 \mathrm{~g} / \mathrm{L}$ acetic acid } \\
\hline $\mathrm{ZM} 4+\mathrm{C}$ & 108 & $51.17 \pm 0.10$ & $21.79 \pm 0.17^{* * *}$ & $0.43 \pm 0.00^{* * *}$ & $0.20 \pm 0.00$ & 84.15 & \\
\hline ZM4 & - & $51.27 \pm 0.04$ & $0.06 \pm 0.04$ & $0.00 \pm 0.00$ & - & - & \\
\hline \multicolumn{8}{|c|}{$100.0 \mathrm{~g} / \mathrm{L}$ glucose $+6.3 \mathrm{~g} / \mathrm{L}$ acetic acid, pH 6.0} \\
\hline ZM401 & 24 & 99.9 & 48.9 & 0.49 & 2.04 & 95.89 & {$[30]$} \\
\hline \multicolumn{8}{|c|}{$50.0 \mathrm{~g} / \mathrm{L}$ glucose $+8.0 \mathrm{~g} / \mathrm{L}$ acetic acid } \\
\hline AQ8-1 & 64 & 49.59 & 20.76 & 0.42 & 0.32 & 82.19 & [10] \\
\hline AC8-9 & 72 & 41.85 & 21.46 & 0.43 & 0.30 & 84.15 & \\
\hline \multicolumn{6}{|c|}{$50.0 \mathrm{~g} / \mathrm{L}$ glucose $+1.0 \mathrm{~g} / \mathrm{L}$ furfural } & & This study \\
\hline $\mathrm{ZM} 4+\mathrm{C}$ & 12 & $51.39 \pm 0.02$ & $23.77 \pm 0.14^{* *}$ & $0.46 \pm 0.00^{* *}$ & $1.98 \pm 0.01^{* * *}$ & 90.02 & \\
\hline ZM4 & 28 & $51.39 \pm 0.04$ & $22.57 \pm 0.23$ & $0.44 \pm 0.00$ & $0.81 \pm 0.01$ & 86.11 & \\
\hline \multicolumn{8}{|c|}{$50.0 \mathrm{~g} / \mathrm{L}$ glucose $+2.0 \mathrm{~g} / \mathrm{L}$ furfural } \\
\hline $\mathrm{ZM} 4+\mathrm{C}$ & 16 & $51.04 \pm 0.47$ & $23.57 \pm 0.53$ & $0.46 \pm 0.01^{*}$ & $1.47 \pm 0.03^{* * *}$ & 90.02 & \\
\hline ZM4 & 32 & $51.28 \pm 0.56$ & $22.21 \pm 0.79$ & $0.43 \pm 0.01$ & $0.69 \pm 0.02$ & 84.15 & \\
\hline \multicolumn{8}{|c|}{$50.0 \mathrm{~g} / \mathrm{L}$ glucose $+3.0 \mathrm{~g} / \mathrm{L}$ furfural } \\
\hline $\mathrm{ZM} 4+\mathrm{C}$ & 24 & $51.42 \pm 0.06$ & $23.99 \pm 0.88$ & $0.47 \pm 0.02$ & $1.00 \pm 0.04^{* * *}$ & 91.98 & \\
\hline ZM4 & 72 & $51.28 \pm 0.19$ & $22.74 \pm 0.62$ & $0.44 \pm 0.01$ & $0.32 \pm 0.01$ & 86.11 & \\
\hline \multicolumn{8}{|c|}{$50.0 \mathrm{~g} / \mathrm{L}$ glucose $+4.0 \mathrm{~g} / \mathrm{L}$ furfural } \\
\hline $\mathrm{ZM} 4+\mathrm{C}$ & 48 & $51.18 \pm 0.12^{* *}$ & $22.82 \pm 0.85^{*}$ & $0.45 \pm 0.02^{*}$ & $0.48 \pm 0.02^{* * *}$ & 88.06 & \\
\hline ZM4 & 84 & $51.64 \pm 0.09$ & $20.35 \pm 1.09$ & $0.39 \pm 0.02$ & $0.24 \pm 0.01$ & 76.32 & \\
\hline \multicolumn{8}{|c|}{$20.0 \mathrm{~g} / \mathrm{L}$ glucose $+3.0 \mathrm{~g} / \mathrm{L}$ furfural } \\
\hline F211 & 22 & N/A & N/A & 0.46 & N/A & 90.02 & [16] \\
\hline F27 & 28 & N/A & N/A & 0.47 & N/A & 91.98 & \\
\hline \multicolumn{8}{|c|}{$20.0 \mathrm{~g} / \mathrm{L}$ glucose $+3.0 \mathrm{~g} / \mathrm{L}$ furfural } \\
\hline ZM4-MF2 & 54 & 20 & 9.8 & 0.49 & 0.181 & 95.89 & {$[31]$} \\
\hline
\end{tabular}

$P$ values calculated by one-way ANOVA, * $P<0.05 ; * * 0<0.01 ; * * * 0.001$

Three repeats were performed for each fermentation

$80 \%$ glucose within $48 \mathrm{~h}$ [4]. In addition, mutant ZM4MF2 was obtained by error-prone PCR of the global transcription sigma factor RpoD in $Z$. mobilis ZM4, which consumed $92.8 \%$ glucose and produced $9.8 \mathrm{~g} / \mathrm{L}$ ethanol within $54 \mathrm{~h}$ in the presence of $3.0 \mathrm{~g} / \mathrm{L}$ furfural under 20.0 g/L glucose [31]. However, with $3.5 \%$ biochar addition, strain ZM4 could consume $99.71 \%$ glucose and produce $23.99 \pm 0.88 \mathrm{~g} / \mathrm{L}$ ethanol within $24 \mathrm{~h}$ in the presence of $3.0 \mathrm{~g} / \mathrm{L}$ furfural under $50.0 \mathrm{~g} / \mathrm{L}$ glucose, which was more efficient in ethanol production under furfural stress condition than some of the previously reported inhibition-tolerant mutant. Thus, BMEEF was more efficient and convenient than the genetic engineering of strains.

\section{Biochar improved ethanol production under acetic acid and furfural stress}

Lignocellulosic hydrolysate is a complex system, and the high abundance of furfural can form synergistic inhibition with acetic acid [6]. Therefore, the BMEEF under co-stress by acetic acid and furfural was investigated. The 
concentrations of two inhibitors in a mixture were 6.0 and $3.0 \mathrm{~g} / \mathrm{L}$, respectively. As shown in Fig. 2a, b, strain ZM4 was dramatically suppressed by a mixture of these two inhibitors. While with $3.5 \%$ biochar addition, strain ZM4 consumed $97.15 \%$ of the initial glucose and produced $22.05 \pm 0.58 \mathrm{~g} / \mathrm{L}$ ethanol after fermentation $48 \mathrm{~h}$, and in less than $60 \mathrm{~h}$, strain ZM4 in untreated fermentation broth consumed $51.17 \%$ of the glucose. So far, there are few studies on multi-resistant $Z$. mobilis strains. The $Z$. mobilis mutant AcRIM0347 obtained by $h f q$ gene insertion of Z. mobilis AcR was resistant to $0.75 \mathrm{~g} / \mathrm{L}$ HMF, $1 \mathrm{~g} / \mathrm{L}$ furfural or $1 \mathrm{~g} / \mathrm{L}$ vanillin for 16,19 or $21 \mathrm{~h}$, respectively [9]. Although the mutant AcRIM0347 is resistant to a variety of inhibitors, the assay did not investigate a mixture of inhibitors. Thus, BMEEF might be a promising strategy to improve ethanol production under practical complex conditions with a variety of inhibitors.

\section{Mechanisms for BMEEF}

\section{Cell immobilization on biochar}

The SEM images presented in Fig. 3 (biochar with $Z$. mobilis in RM medium, with $Z$. mobilis in RM medium supplemented with $6.0 \mathrm{~g} / \mathrm{L}$ acetic acid, and with $Z$. mobilis in RM medium supplemented with $3.0 \mathrm{~g} / \mathrm{L}$ furfural) highlighted the potential of biochar to provide a suitable habitat for microbial colonization. Cell immobilization on biochar in the fermentation broth and subsequent remarkable promotion of biofuel production were also observed by the ethanol fermentation by $S$. cerevisiae and $K$. marxianus in the presence of biowaste-derived biochar [25, 32]. However, the previous results about cell immobilization were obtained under conditions without inhibitors [33]. Here, the cell immobilization of Z. mobilis was observed under inhibition conditions, and, more importantly, immobilized Z. mobilis on biochar showed unexpected resistance to inhibitions. Thus, immobilizing $Z$. mobilis densely and homogeneously to the surface of biochar could be a novel strategy for bioethanol production, especially for bioethanol production under the practical condition with multi-inhibitors.

Two stages might be involved in the immobilization of microbes on biochar. The initial stage might be the adsorption of microbes onto biochar, which could be interpreted by the theory of colloid stability, and the second stage might be the biofilm formation [34, 35]. Cell immobilization on the surface of the biochar is a result of either physical adsorption by electrostatic force or due to natural cell attachment into the porous or covalent binding between the membrane and the support [36]. Further studies are needed to elucidate the formation of cell immobilization on biochar and the effects of immobilized ethanologenic strains on inhibition mitigation.

\section{Unexpected effects of biochar extracts}

Biochar in RM medium with inhibitor $(8.0 \mathrm{~g} / \mathrm{L}$ acetic acid or $4.0 \mathrm{~g} / \mathrm{L}$ furfural) was filtered before strain inoculation to confirm the effects of biochar extracts on ethanol fermentation. As shown in Fig. 4, in the presence of $8.0 \mathrm{~g} / \mathrm{L}$ acetic acid, strain ZM4 in the filtered biochartreated medium showed a faster fermentation rate and consumed $93.98 \%$ glucose within $48 \mathrm{~h}$, while strain ZM4 in biochar-untreated medium only consumed $30.44 \%$ glucose in less than $24 \mathrm{~h}$. Moreover, in the presence of $4.0 \mathrm{~g} / \mathrm{L}$ furfural, the fermentation time of ZM4 in the filtered biochar-treated medium was reduced by $24 \mathrm{~h}$, compared to the biochar-untreated system. Thus, these results suggested that biochar extract promoted ethanol fermentation under stress conditions.
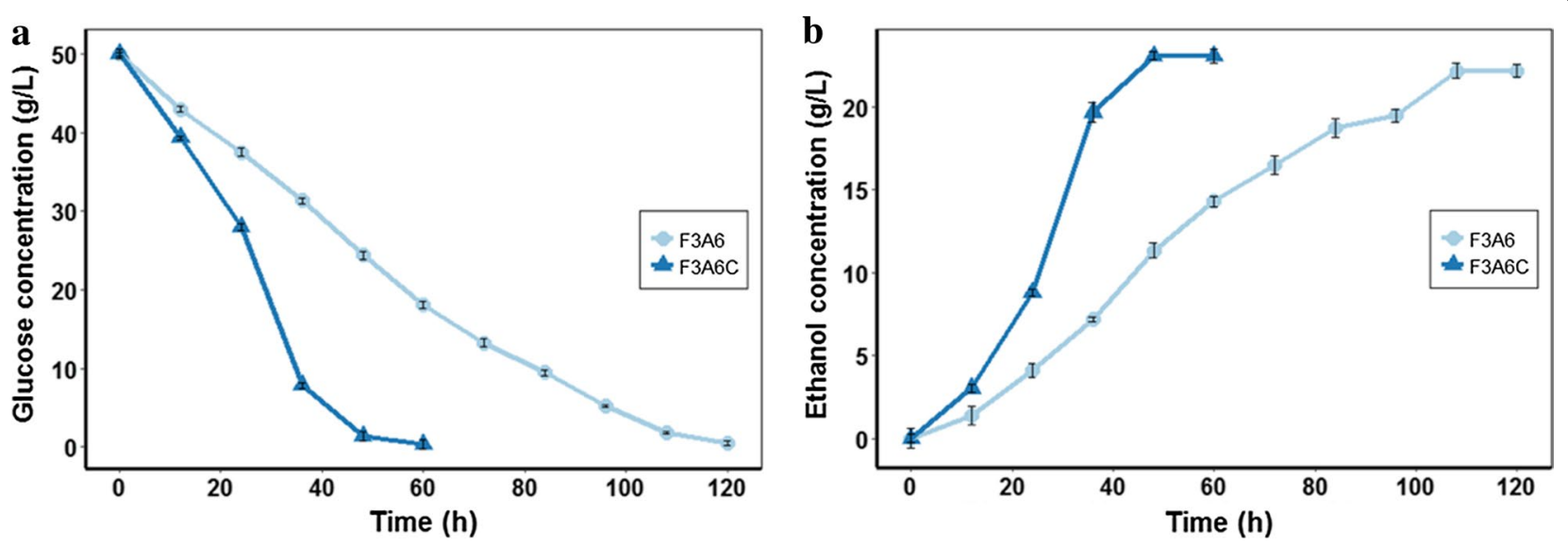

Fig. 2 Effects of biochar on ethanol fermentation by Z. mobilis ZM4 in the presence of $3.0 \mathrm{~g} / \mathrm{L}$ furfural plus $6.0 \mathrm{~g} / \mathrm{L}$ acetic acid. a Glucose consumption. b Ethanol yield. F3A6 indicates Z. mobilis ZM4 fermented in the presence of $3.0 \mathrm{~g} / \mathrm{L}$ furfural plus $6.0 \mathrm{~g} / \mathrm{L}$ acetic acid. "F3A6C" indicates Z. mobilis ZM4 co-cultured with 3.5\% biochar fermented in the presence of $3.0 \mathrm{~g} / \mathrm{L}$ furfural plus $6.0 \mathrm{~g} / \mathrm{L}$ acetic acid 

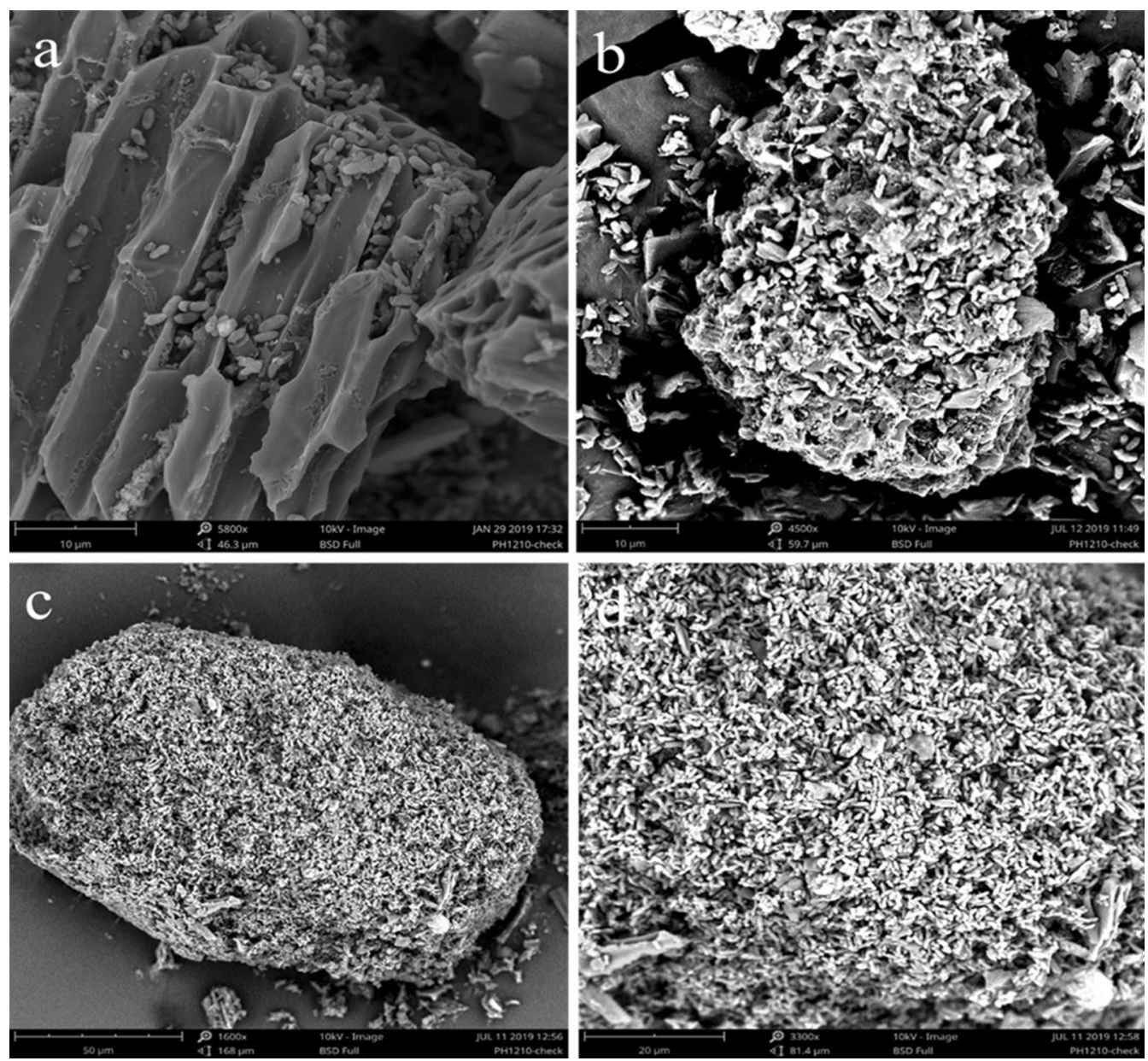

Fig. 3 SEM of Z. mobilis interaction with biochar. a Biochar in RM medium with Z. mobilis. b Biochar in RM medium supplemented with $6.0 \mathrm{~g} / \mathrm{L}$ acetic acid with Z. mobilis. c, d Biochar in RM medium supplemented with $3.0 \mathrm{~g} / \mathrm{L}$ furfural with Z. mobilis
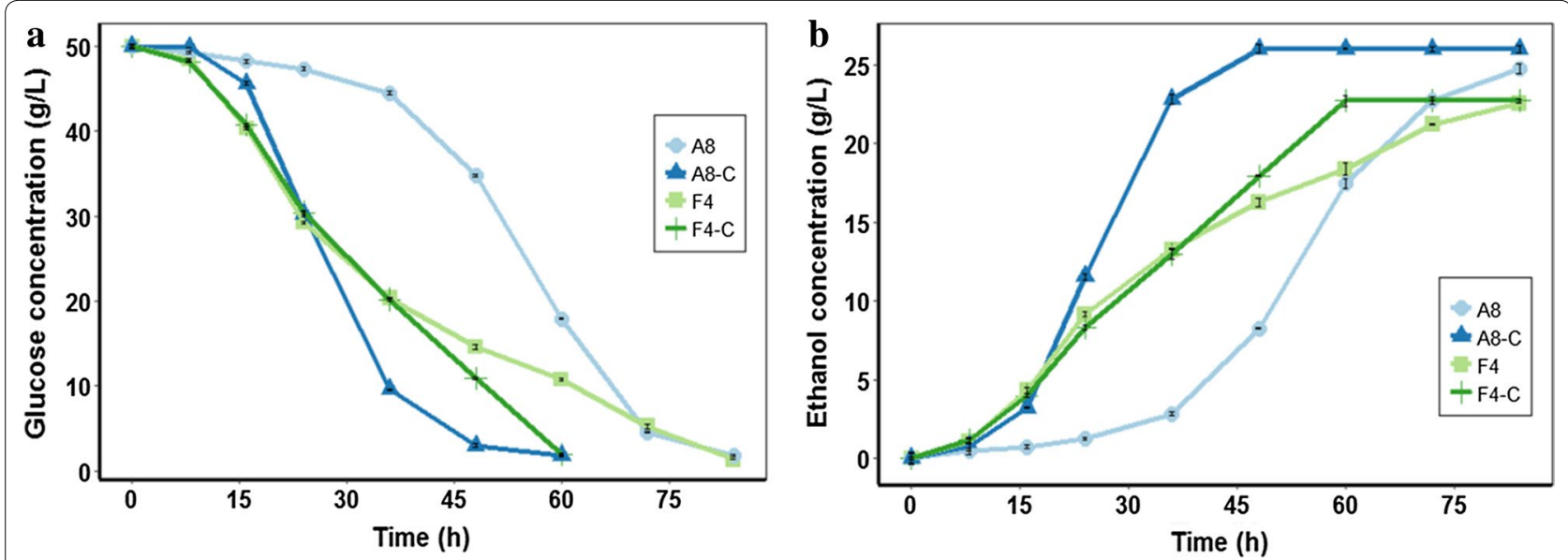

Fig. 4 Effects of filtered medium of biochar on ethanol fermentation by Z. mobilis ZM4 "A8" and "F4" indicate Z. mobilis ZM4 fermented in the presence of $8.0 \mathrm{~g} / \mathrm{L}$ acetic acid and $4.0 \mathrm{~g} / \mathrm{L}$ furfural, respectively. "A8-C" and "F4-C" indicate Z. mobilis ZM4 co-cultured with filtered biochar-treated medium in the presence of $8.0 \mathrm{~g} / \mathrm{L}$ acetic acid and $4.0 \mathrm{~g} / \mathrm{L}$ furfural, respectively 
To further elucidate the effects of biochar extract, the nutrients in biochar-treated medium were investigated. Actually, $719.5 \mathrm{mg} / \mathrm{L} \mathrm{TN}, 806 \mathrm{mg} / \mathrm{L}$ TOC, $674.2 \mathrm{mg} / \mathrm{L} \mathrm{TP}$, $193.2 \mathrm{mg} / \mathrm{L} \mathrm{K}$, and $12.03 \mathrm{mg} / \mathrm{L} \mathrm{Mg}$ were detected in biochar-filtered medium, which were improved compared to raw RM medium. As previously reported, the glucose utilization of $Z$. mobilis is controlled by coupled phosphorylation; the addition of inorganic phosphate will lead to an improvement in the utilization of glucose by Z. mobilis, and $\mathrm{Mg}^{2+}$ ions, which has been confirmed to protect the viability of $Z$. mobilis via preventing the breakdown of RNA under starvation [37]. Besides, $\mathrm{K}^{+}$ions are a cofactor of the most intracellular enzyme, and this property may benefit the growth of $Z$. mobilis and resistance to inhibitors. What's more, some small molecules in biochar might act as allosteric regulators of a specific enzyme to facilitate resistance to inhibitors in the strain, and this needs further study. Thus, these results suggested that biochar could provide extra nutrients for promoting strain ZM4 resistant to acetic acid and furfural, facilitating ethanol production under stress conditions.

\section{Beyond adsorptive detoxification}

Inhibitors such as furfural and HMF were prone to be adsorbed. However, a little adsorbent is highly efficient for acetic acid adsorption. Thus, adsorbable furfural and non-adsorbable acetic acid were chosen as two types of inhibitors in this study. As shown in Fig. 5, biochar adsorbed $15.25 \%$ and $18.75 \%$ of furfural in the presence of 3.0 and $4.0 \mathrm{~g} / \mathrm{L}$ furfural within $12 \mathrm{~h}$, respectively, indicating that the furfural concentration in the fermentation broth was still very high. In addition, the concentration of acetic acid was nearly invariable during the entire fermentation process (Additional file 1: Figure S1). Thus,

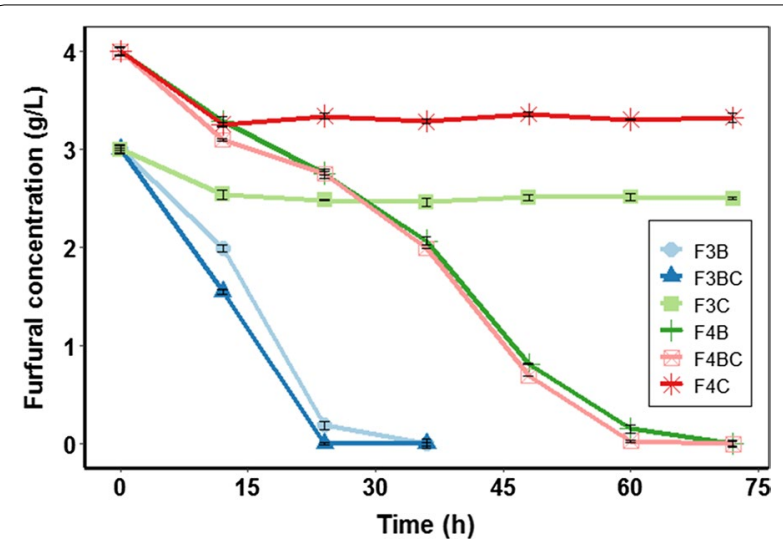

Fig. 5 Effects of biochar on the adsorption of furfural. "FnB" indicates Z. mobilis ZM4 fermented in the presence of $n \mathrm{~g} / \mathrm{L}$ furfural. "FnBC" indicates Z. mobilis ZM4 co-cultured with 3.5\%o biochar fermented in the presence of $n \mathrm{~g} / \mathrm{L}$ furfural. "FnC" indicates biochar in the presence of $n \mathrm{~g} / \mathrm{L}$ furfural these results suggested that adsorptive removal of inhibitors might not be the dominant mechanism for enhanced ethanol production under stress conditions.

Compared to traditional adsorptive detoxification [27], attributed to the low dose of biochar (3.5\%), the removal efficiency for furfural was lower in this study. For example, modified biochar from bamboo at a dose of $75 \mathrm{~g} / \mathrm{L}$ was applied for furfural adsorption, and almost $100 \%$ furfural was removed in $10 \mathrm{~g} / \mathrm{L}$ furfural solution [27]. However, for BMEEF, biochar was not used as an adsorbent for adsorptive detoxification, but as an additive. Thus, for BMEEF, strains were allowed to exist with a low dose of biochar and a certain amount of inhibitors in the fermentation broth.

Furthermore, compared to biochar application in other areas, e.g., soil amendment [19], anaerobic digestion [21, 22], and composting [23], attributed to its much lower application amount, the $\mathrm{pH}$ changes in BMEEF were not remarkable (Additional file 1: Figure S1). It only increased by 0.05 in all test conditions. Thus, $\mathrm{pH}$ adjustment was not responsible for enhanced ethanol production.

\section{Biochar-mediated enhanced ethanol fermentation (BMEEF)}

In this study, BMEEF was developed using 3.5\%o biochar as an additive to promote ethanol production, especially under stress conditions, not just as an adsorbent to remove inhibitors. Adsorptive removal of inhibitors by various adsorbents, e.g., biochar, activated carbon, has been developed for inhibition mitigation or detoxification. However, these adsorbents are not used as an additive in the fermentation broth, but used as a detoxification agent and removed out before ethanol fermentation [28]. When biochar was applied as a detoxification agent, it focused on the high removal of inhibitors. For example, previous results showed that more than $94 \%$ of 5 -HMF and $99 \%$ of furfural were removed in the synthetic medium after $24 \mathrm{~h}$ of contact time by $4 \%$ biochar [28]. However, for BMEEF, the amount of biochar was as low as $3.5 \%$, which was much lower than the amount used in detoxification. Moreover, the removal of furfural by $3.5 \%$ o biochar was $<20 \%$, and no obvious decrease of acetic acid in the fermentation broth was observed. Thus, adsorptive detoxification was not critical for BMEEF, and strains were allowed to exist with a low dose of biochar and a certain amount of inhibitors.

Even under non-stress conditions, BMEEF could remarkably promote ethanol fermentation by $Z$. mobilis. As shown in Additional file 1: Figure S2, ethanol production in biochar-added RM medium without any inhibitors was investigated to confirm the effects of biochar on ethanol production. Results showed that, with the addition of $3.5 \%$ biochar in RM medium without any 
inhibitors, strain ZM4 consumed nearly $100 \%$ glucose and produced $27.44 \mathrm{~g} / \mathrm{L}$ ethanol within $7.5 \mathrm{~h}$, and in less than $4.5 \mathrm{~h}$, strain ZM4 consumed $55.16 \%$ glucose and produced $15.09 \mathrm{~g} / \mathrm{L}$ ethanol, indicating that biochar facilitated strain growth and subsequent ethanol production under non-stress conditions.

Mechanism analysis further suggested that BMEEF was not dependent on adsorptive detoxification due to its low removal for furfural and incapability in acetic acid removal in the fermentation broth, but dependent on the cell immobilization on biochar surface and biochar extract to supply nutrients (or some possible small organic molecules) to the broth. Further studies are needed to elucidate the formation process of cell immobilization on biochar, functional components in biochar extract, and their effects on strain growth and ethanol production under stress conditions.

Furthermore, attributed to the inhibition mitigation effects of BMEEF, it might be competent for the fermentation in concentrated hydrolysate with a high concentration of glucose and thus for the production of high concentration of ethanol in the fermentation broth, which needs further study. The immobilized strain on biochar might facilitate the recovery of strains in the fermentation broth, which could be beneficial for repeated batch fermentation $[25,32]$.

\section{Conclusion}

In this study, the performance of BMEEF under various stress conditions (furfural and acetic acid) was first investigated. Results showed that with 3.5\% (w/v) biochar in the fermentation broth, ethanol production was remarkably enhanced in the presence of high concentrations of furfural and acetic acid, especially under co-stress conditions. Further analysis showed that BMEEF was not dependent on adsorptive removal of inhibitors due to its low removal for furfural and incapability in acetic acid removal in the fermentation broth, but dependent on the cell immobilization on biochar surface and biochar extracts to supply nutrients (or some possible small organic molecules) to the broth. Thus, BMEEF might be a promising strategy for ethanol production from lignocellulosic biomass.

\section{Materials and methods}

\section{Treatment of media and bacterial preparation}

Zymomonas mobilis wild-type strain ZM4 was grown in rich medium $(20.0 \mathrm{~g} / \mathrm{L}$ glucose, $10.0 \mathrm{~g} / \mathrm{L}$ yeast extract and $2.0 \mathrm{~g} / \mathrm{L} \mathrm{KH}_{2} \mathrm{PO}_{4}$ ) for the overnight stock culture. Biochar was prepared via the pyrolysis of wheat straw at $600{ }^{\circ} \mathrm{C}$ for $2 \mathrm{~h}$ at a heating rate of $10{ }^{\circ} \mathrm{C} / \mathrm{min}$ in a vacuum tube furnace (MXQ1200-30, China) and then sieved to a particulate size of $80 \mathrm{~mm}$ [38].
Cultures were inoculated from a fresh plate of RM. The overnight stock culture was cultured for $12 \mathrm{~h}$ at $30{ }^{\circ} \mathrm{C}$ without shaking. The final optical density (OD) (Jingke UV765, Shanghai) of the overnight stock culture at $600 \mathrm{~nm}$ was 1.8. The $\mathrm{OD}_{600}$ was measured to assess the rate of bacterial growth. To $50 \mathrm{~mL}$ of RM medium, 3.5\% (by weight, $0.175 \mathrm{~g}$ ) biochar was added. Cell pellets were harvested from $2 \mathrm{~mL}$ of the overnight stock culture by centrifuging at $3000 \mathrm{rpm}$ for $4 \mathrm{~min}$ at $4{ }^{\circ} \mathrm{C}$. The harvested cell pellets were then inoculated into the two different media (RM and biochar-treated medium) to begin bacterial growth. In this set of experiments, bacteria grew in the presence of biochar or untreated RM medium throughout the time course (12 h) of each experiment. All growth and fermentations were carried out in triplicate.

An additional set of experiments was performed to investigate the influence of the biochar on typical inhibitors (adsorbable furfural and non-adsorbable acetic acid) generated during lignocellulose pretreatment. For these experiments, $3.5 \%$ o (by weight, $0.175 \mathrm{~g}$ ) biochar was added to $50 \mathrm{~mL}$ RM media (in $100 \mathrm{~mL}$ flask) with different acetic acid concentrations (3.0, 6.0, 9.0, and $12.0 \mathrm{~g} / \mathrm{L}$ ), or different furfural concentrations (1.0, 2.0, 3.0, and 4.0), or $6.0 \mathrm{~g} / \mathrm{L}$ acetic acid plus $3.0 \mathrm{~g} / \mathrm{L}$ furfural. Meanwhile, biochar-untreated RM medium was also supplemented with the corresponding concentrations of acetic acid or/and furfural as a control. $2 \mathrm{~mL}$ of the overnight stock culture was harvested and inoculated into each flask and placed in the incubator at $30{ }^{\circ} \mathrm{C}$ without shaking. All growth and fermentations were carried out in triplicate.

In addition, the third set of experiments was performed where biochar was removed from the medium before inoculation. For these experiments, the same 3.5\%o (by weight, $0.175 \mathrm{~g}$ ) biochar was added to $50 \mathrm{~mL}$ RM media with $8.0 \mathrm{~g} / \mathrm{L}$ acetic acid and $4.0 \mathrm{~g} / \mathrm{L}$ furfural, respectively. Then the media was first filtered through a $0.45-\mu \mathrm{m}$ sterile syringe filter and then passed through a $0.22-\mu \mathrm{m}$ sterile syringe filter. Meanwhile, as a comparison, biochar-untreated RM medium was also supplemented with $8.0 \mathrm{~g} / \mathrm{L}$ acetic acid and $4.0 \mathrm{~g} / \mathrm{L}$ furfural, respectively. Cultivation methods were the same as the first and second sets of experiments. All cell growth and ethanol fermentation were carried out in triplicate.

\section{Characteristics of biochar}

The mineral elements (e.g., $\mathrm{K}, \mathrm{Mg}$ ) present in the biochar were determined by ICP (PlasmaQuant PQ9000, Germany). The $\mathrm{N}$ content in the biochar was determined by a TN analyzer (SHIMADZU, Japan). The total carbon (TC) content and total organic carbon (TOC) contents were determined by a TOC-V CPH analyzer (SHIMADZU, Japan). 


\section{SEM analysis}

Biochar inoculated with Z. mobilis ZM4 cells was imaged using scanning electron microscope (SEM). Samples were prepared by chemical fixation and freeze-drying. Briefly, two milliliters of the co-cultures was first fixed with $2.5 \%$ glutaraldehyde at $4{ }^{\circ} \mathrm{C}$ for $12 \mathrm{~h}$, rinsed by $0.1 \mathrm{M}$ PBS buffer ( $\mathrm{pH} 7.0$ ) twice, dehydrated with graded ethanol, treated with isoamyl acetate (for replacement of ethanol), and then the samples were observed by scanning electron microscope (Phenom Pro, Netherlands Phenom) after freeze-drying.

\section{Analytical methods}

After filtration with a $0.22-\mu \mathrm{m}$ membrane and ten-time dilution, the concentrations of glucose, ethanol, acetic acid, and furfural in fermentation medium were analyzed by high-performance liquid chromatography (HPLC; Agilent 1200), equipped with refractive index detector. An HPX-87H ion exclusion column (Bio-Rad Aminex) was used at $65^{\circ} \mathrm{C}$ with $5 \mathrm{mM} \mathrm{H}_{2} \mathrm{SO}_{4}$ as the mobile phase and run at a flow rate of $0.6 \mathrm{~mL} / \mathrm{min}$. The injection volume was set to $20.0 \mu \mathrm{L}$. One-way ANOVA was used to test all experimental data and the correlation was analyzed with the Pearson test (two tailed) using Statistical Product and Service Solutions Software (SPSS, version 19.0).

\section{Supplementary information}

Supplementary information accompanies this paper at https://doi. org/10.1186/s13068-020-1666-6.

Additional file 1: Figure S1. Biochar-facilitated ethanol fermentation in acetic acid stress conditions. No acetic acid removal (a), and little pH changes (b). Figure S2. Effects of biochar on ethanol fermentation by $Z$. mobilis ZM4 in the presence of RM medium. "RM" indicates Z. mobilis ZM4 fermented in RM medium. "RMC" indicates Z. mobilis ZM4 co-cultured with 3.5\% biochar fermented in RM medium.

\section{Abbreviations}

BMEEF: Biochar-mediated enhanced ethanol fermentation; ARTP: Atmospheric and room temperature plasma; ALE: Adaptive laboratory evolution; NTG: $N$-Methyl-N-nitro-N-nitrosoguanidine; RM: Rich medium; OD: Optical density; HPLC: High-performance liquid chromatography; SEM: Scanning electron microscope.

\section{Acknowledgements}

This research was financially supported by the National Natural Sciences Foundation of China (Grant nos. 31570055 and 21707074), Central Publicinterest Scientific Institution Basal Research Fund (No. Y2019XK23-01), Special Fund for Agro-scientific Research in the Public Interest (201403019), and the Elite Program and Basic Research Program of Chinese Academy of Agricultural Sciences.

\section{Authors' contributions}

MXH designed the whole study and wrote the final manuscript. WTW carried out all experiments, data collection, and manuscript editing. LCD prepared he biochar sample, designed the experiment, and revised the manuscript. BW participated in data analysis. BFQ helped in the use of TN, TOC-V CPH and ICP analyzer. TFH helped in the use of SEM. GQH participated in helpful discussions regarding the manuscript and helped in its editing. All authors read and approved the final manuscript.

\section{Funding}

Mingxiong He was financially supported by National Natural Science Foundation of China (Grant no. 31570055), Central Public-interest Scientific Institution Basal Research Fund (No. Y2019XK23-01), and the Elite Program and Basic Research Program of Chinese Academy of Agricultural Sciences.

Lichun Dai was financially supported by the National Natural Sciences Foundation of China (Grant no. 21707074).

Guoquan Hu was financially supported by Special Fund for Agro-scientific

Research in the Public Interest (201403019).

\section{Availability of data and materials}

Z. mobilis AQ8-1 and AC8-9 have been deposited at Guangdong Microbial Culture Center (GDMCC) under the Accession number GDMCC60258 and 60259.

\section{Ethics approval and consent to participate}

Not applicable.

\section{Consent for publication \\ Not applicable.}

\section{Competing interests}

The authors declare that they have no competing interests.

\section{Author details}

${ }^{1}$ Biomass Energy Technology Research Centre, Key Laboratory of Development and Application of Rural Renewable Energy (Ministry of Agriculture and Rural Affairs), Biogas Institute of Ministry of Agriculture and Rural Affairs, Section 4-13, Renmin Rd. South, Chengdu 610041, People's Republic of China. ${ }^{2}$ Graduate School of Chinese Academy of Agricultural Science, Beijing 100081 People's Republic of China. ${ }^{3}$ College of Pharmacy and Biological Engineering, Chengdu University, No. 2025, Cheng Luo Road, Chengdu 610106, People's Republic of China. ${ }^{4}$ Chengdu Institute of Biology, Chinese Academy of Sciences, Section 4-9, Renmin Rd. South, Chengdu 610041, People's Republic of China.

Received: 8 October 2019 Accepted: 22 January 2020

Published online: 26 February 2020

\section{References}

1. Harmsen P, Huijgen W, Bermudez L, Bakker R. Literature review of physical and chemical pretreatment processes for lignocellulosic biomass. Wageningen UR-Food Biobased Research; 2010.

2. He MX, Wu B, Shui ZX, Hu QC, Wang WG, Tan FR, Tang XY, Zhu QL, Pan K, Li Q. Transcriptome profiling of Zymomonas mobilis under furfural stress. Appl Microbiol Biotechnol. 2012;95(1):189-99.

3. Lawford HG, Rousseau JD. Cellulosic fuel ethanol. In: Biotechnology for fuels and chemicals; 2003. p. 457-69.

4. Shui ZX, Qin H, Wu B, Ruan ZY, Wang LS, Tan FR, Wang JL, Tang XY, Dai LC, Hu GQ. Adaptive laboratory evolution of ethanologenic Zymomonas mobilis strain tolerant to furfural and acetic acid inhibitors. Appl Microbiol Biotechnol. 2015:99(13):5739-48.

5. Almeida JR, Modig T, Petersson A, Hähn-Hägerdal B, Lidén G, GorwaGrauslund MF. Increased tolerance and conversion of inhibitors in lignocellulosic hydrolysates by Saccharomyces cerevisiae. J Chem Technol Biotechnol Int Res Process Environ Clean Technol. 2007;82(4):340-9.

6. Almeida JR, Bertilsson M, Gorwa-Grauslund MF, Gorsich S, Lidén G. Metabolic effects of furaldehydes and impacts on biotechnological processes. Appl Microbiol Biotechnol. 2009;82(4):625.

7. Dong H, Bao J. Metabolism: biofuel via biodetoxification. Nat Chem Biol. 2010;6(5):316

8. Mussatto SI, Roberto IC. Alternatives for detoxification of diluted-acid lignocellulosic hydrolyzates for use in fermentative processes: a review. Bioresour Technol. 2004;93(1):1-10. 
9. Yang S, Pelletier DA, Lu T-YS, Brown SD. The Zymomonas mobilis regulator hfa contributes to tolerance against multiple lignocellulosic pretreatment inhibitors. BMC Microbiol. 2010;10(1):135.

10. Wu B, Qin H, Yang Y, Duan G, Yang S, Xin F, Zhao C, Shao H, Wang Y, Zhu Q, et al. Engineered Zymomonas mobilis tolerant to acetic acid and low pH via multiplex atmospheric and room temperature plasma mutagenesis. Biotechnol Biofuels. 2019;12(1):10

11. Yang S, Fei Q, Zhang Y, Contreras LM, Utturkar SM, Brown SD, Himmel ME, Zhang M. Zymomonas mobilis as a model system for production of biofuels and biochemicals. Microb Biotechnol. 2016;9(6):699-717.

12. He MX, Wu B, Qin H, Ruan ZY, Tan FR, Wang JL, Shui ZX, Dai LC, Zhu QL, Pan K. Zymomonas mobilis: a novel platform for future biorefineries. Biotechnol Biofuels. 2014;7(1):101.

13. Franden MA, Pilath HM, Mohagheghi A, Pienkos PT, Zhang M. Inhibition of growth of Zymomonas mobilis by model compounds found in lignocellulosic hydrolysates. Biotechnol Biofuels. 2013;6(1):99.

14. Xia J, Yang Y, Liu C-G, Yang S, Bai F-W. Engineering Zymomonas mobilis for robust cellulosic ethanol production. Trends Biotechnol. 2019. https://doi. org/10.1016/j.tibtech.2019.02.002.

15. Wang $X$, He Q, Yang $Y$, Wang J, Haning $K$, Hu Y, Wu B, He M, Zhang Y, Bao J, et al. Advances and prospects in metabolic engineering of Zymomonas mobilis. Metab Eng. 2018;50:57-73.

16. Huang $S$, Xue T, Wang Z, Ma Y, He X, Hong J, Zou S, Song H, Zhang M. Furfural-tolerant Zymomonas mobilis derived from error-prone PCR-based whole genome shuffling and their tolerant mechanism. Appl Microbiol Biotechnol. 2018;102(7):3337-47.

17. Dai L, Tan F, Li H, Zhu N, He M, Zhu Q, Hu G, Wang L, Zhao J. Calcium-rich biochar from the pyrolysis of crab shell for phosphorus removal. J Environ Manag. 2017;198(Part 1):70-4

18. Dai L, Zhu W, He L, Tan F, Zhu N, Zhou Q, He M, Hu G. Calcium-rich biochar from crab shell: an unexpected super adsorbent for dye removal. Bioresour Technol. 2018;267:510-6.

19. O'Connor D, Peng T, Zhang J, Tsang DC, Alessi DS, Shen Z, Bolan NS, Hou D. Biochar application for the remediation of heavy metal polluted land: a review of in situ field trials. Sci Total Environ. 2018;619:815-26.

20. Biederman LA, Harpole WS. Biochar and its effects on plant productivity and nutrient cycling: a meta-analysis. GCB Bioenergy. 2013;5(2):202-14.

21. Lü F, Liu Y, Shao L, He P. Powdered biochar doubled microbial growth in anaerobic digestion of oil. Appl Energy. 2019;247:605-14.

22. Wang D. Improving anaerobic digestion of easy-acidification substrates by promoting buffering capacity using biochar derived from vermicompost. Bioresour Technol. 2017:227:286-96.

23. Novak J, Moore E, Spokas K, Hall K, Williams A. Future biochar research directions. Biochar from biomass and waste. Amsterdam: Elsevier; 2019. p. 423-35.

24. Sambusiti C, Monlau F, Antoniou N, Zabaniotou A, Barakat A. Simultaneous detoxification and bioethanol fermentation of furans-rich synthetic hydrolysate by digestate-based pyrochar. J Environ Manag. 2016;183:1026-31.

25. Kyriakou M, Chatziiona VK, Costa CN, Kallis M, Koutsokeras L, Constantinides G, Koutinas M. Biowaste-based biochar: a new strategy for fermentative bioethanol overproduction via whole-cell immobilization. Appl Energy. 2019;242:480-91.

26. Richard D, Núnez MDLD, Schweich D. Adsorption of complex phenolic compounds on active charcoal: adsorption capacity and isotherms. Chem Eng J. 2009;148(1):1-7.

27. Li Y, Shao J, Wang X, Deng Y, Yang H, Chen H. Characterization of modified biochars derived from bamboo pyrolysis and their utilization for target component (furfural) adsorption. Energy Fuels. 2014;28(8):5119-27.

28. Monlau F, Sambusiti C, Antoniou N, Zabaniotou A, Solhy A, Barakat A. Pyrochars from bioenergy residue as novel bio-adsorbents for lignocellulosic hydrolysate detoxification. Bioresour Technol. 2015;187:379-86.

29. Mills TY, Sandoval NR, Gill RT. Cellulosic hydrolysate toxicity and tolerance mechanisms in Escherichia coli. Biotechnol Biofuels. 2009;2(1):26.

30. Zhao N, Bai Y, Liu CG, Zhao XQ, Xu JF, Bai FW. Flocculating Zymomonas mobilis is a promising host to be engineered for fuel ethanol production from lignocellulosic biomass. Biotechnol J. 2014;9(3):362-71.

31. Tan F-R, Dai L-C, Wu B, Qin H, Shui Z-X, Wang J-L, Zhu Q-L, Hu Q-C, Ruan Z-Y, He M-X. Improving furfural tolerance of Zymomonas mobilis by rewiring a sigma factor RpoD protein. Appl Microbiol Biotechnol. 2015:99(12):5363-71.

32. Diallo O. Effect of poultry litter biochar on Saccharomyces cerevisiae growth and ethanol production from steam-exploded poplar and corn stover; 2014.

33. Hill RA, Hunt J, Sanders E, Tran M, Burk GA, Mlsna TE, Fitzkee NC. Effect of biochar on microbial growth: a metabolomics and bacteriological investigation in E. coli. Environ Sci Technol. 2019;53(5):2635-46.

34. Morales CFL, Strathmann M, Flemming H-C. Influence of biofilms on the movement of colloids in porous media. Implications for colloid facilitated transport in subsurface environments. Water Res. 2007:41(10):2059-68.

35. Yallop M, Paterson D, Wellsbury P. Interrelationships between rates of microbial production, exopolymer production, microbial biomass, and sediment stability in biofilms of intertidal sediments. Microb Ecol. 2000;39(2):116-27.

36. Rivera-Utrilla J, Bautista-Toledo I, Ferro-García MA, Moreno-Castilla C. Activated carbon surface modifications by adsorption of bacteria and their effect on aqueous lead adsorption. J Chem Technol Biotechnol. 2001;76(12):1209-15.

37. Dawes EA, Large PJ. Effect of starvation on the viability and cellular constituents of Zymomonas anaerobia and Zymomonas mobilis. J Gen Appl Microbiol. 1970:60(1):31-42

38. Dai L, Bo W, Tan F, He M, Wang W, Han Q, Tang X, Zhu Q, Ke P, Hu Q. Engineered hydrochar composites for phosphorus removal/recovery: lanthanum doped hydrochar prepared by hydrothermal carbonization of lanthanum pretreated rice straw. Bioresour Technol. 2014;161(3):327-32.

\section{Publisher's Note}

Springer Nature remains neutral with regard to jurisdictional claims in published maps and institutional affiliations.

Ready to submit your research? Choose BMC and benefit from

- fast, convenient online submission

- thorough peer review by experienced researchers in your field

- rapid publication on acceptance

- support for research data, including large and complex data types

- gold Open Access which fosters wider collaboration and increased citations

- maximum visibility for your research: over $100 \mathrm{M}$ website views per year

At BMC, research is always in progress.

Learn more biomedcentral.com/submissions 